Vol. 56, 7. 1-2 - 2003

s. $5-20$

\title{
Some agricultural aspects of seed longevity (literature review)
}

\section{ROMAN HOEUBOWICZ', MARIA MOROZOWSKA², TOMASZ W. BRALEWSKI ${ }^{1}$}

\author{
1) Department of Seed Science and Technology, August Cieszkowski Poznań \\ Agricultural University, Baranowo, 62-081 Przeźmierowo, Poland \\ e-mail: rhseed@owl.au.poznan.pl \\ e-mail: twbseed@owl.au.poznan.pl \\ 2) Department of Botany, August Cieszkowski Poznań Agricultural University, \\ 60-625 Poznań, Wojska Polskiego 71 C. Poland \\ e-mail:mariamor@owl.au.poznan.pl
}

(Received: 22.11.2002)

\section{Summary}

There has been a vast and numerous literature concerning seed longevity. Most of these works however has focused solely on theoretical and biological aspects of this problem. Some works although deal with practical problems of seed storage, vigour or deterioration, have had relatively little connection with agricultural crops, practical farming or gardening. Therefore, there has been a need to look at this problem from the seedman's and farmer's point of view. The paper comments on how long seeds of agricultural crops species can keep their longevity, how long it is economically reasonable to store them, the effect of the seeds chemical composition on their longevity, how seeds storage conditions can be modified in order to eventually improve their longevity and environment circumstances influence on the final seed longevity. The paper contains a synthetic summary of expected seed longevity of the most important agricultural species and many examples of long longevity of agricultural species.

Key words: seed, seed longevity, seed deterioration

\section{MAXIMUM SPAN OF AGRICULTURAL SEEDS LIFE}

Because of the ability to persist in the soil, seeds represent the longest living propagules of higher plants, and possibly the oldest living organisms on earth (B u r nside et al., 1996).

Since many years people were interested in learning how long seeds can keep their ability to germinate. There are reports of germination of many seeds of various 
genera taken from the mud of the Thames in 1843, after having been placed (for a short time) in boiling water (C a m b a g e, 1928).

The longevity of seeds is a specific for species, genetically inherited trait. The maximum longevity of seed can not be approximated before the adequate methods for storage and methods for germination are known specifically. The only way to determine today reliably the age of seeds are tests for radiocarbon content and the direct dating of the germinated seed per se (Shen-Miller et al., 1995). With recently improved dating by accelerator mass spectroscopy (AMS) technique radiocarbon can be assayed using a very small amount of tissue (less than $10 \mathrm{mg}$ ). Use of this technique though permits dating only of pericarp, sparing the germinated seed for studies of growth and development (D a v is et al., 1990). Practical agriculture is less interested in detailed information about an age of seed's pericarp. The most important part of any seed, in terms of agriculture, has always been its embryo. In practice though. only seeds of very precious breeding materials are stored longer than 10 years (Tab. 1).

The oldest demonstrably viable and directly dated are seed of the sacred lotus (Nelumbo nucifera Gaertner; Nelumbonaceae) from the Pulantein deposit in China (O h g a , 1926). One of them had a mean physical age, based on radiocarbon dating, of $1,288+271$ years. The morphophysiological characteristics of fruit of the sacred lotustheir impervious and mechanically strong fruit walls, chlorophyllous plumules, robust proteins including the MT protein-repair enzyme, high level of reducing compounds in embryonic axes, and maintenance of membrane fluidity-coupled with the highly reducing anoxic environment of the sedimentary strata in which the Pulantien fruits have been preserved, have all significantly contributed to the exceptional longevity of the seeds (Shen-Miller et al., 1995; Shen-Miller et al., 2002). The oldest viable seeds from herbarium specimens are reported to be 90 years in age (Bewley, B lack, 1982). R oos and Davidson (1992) reported that among many vegetable seeds, the oldest seed lot tested was a tomato cultivar, Marmon, that still germinated after 60 years of storage. Longevity of more than 50 years were also reported for sugar beet (Beta vulgaris L.), corn (Zea mays L.), cucumber (Cucumis sativus L.), eggplant (Solanum melongena L.) and muskmelon (Cucumis melo L.). Thus, seeds of the species from Chenopodiaceae and Cucurbitaceae botanical families, in terms of agricultural and horticultural crops, have had the biggest potential for longevity and practical farming use, i. e. they will keep their viability, germination and ability for field emergence for over 50 years.

Seeds of many species retain their viability longer when buried in the moist soil than when kept dry. There is a certain biological system in seeds to overcome some viability disturbances and abnormalities. The existence of this repair and viability maintenance system in seeds is supposed to correct some seed damage as and when it occurs (Villiers, 1973; Shen-Miller et al., 2002). One of the first such buried studies was initiated by W. J. B e al in East Lansing, Michigan (USA) in 1879. His well documented controlled experiment on the longevity of seed viability showed that of 23 species of seeds subjected to 100 years of burial (1880-1980), the three species: mallow (Malva rotundifolia, Malvaceae), mullein (Verbascum blattaria and V. thapsus, Scrophulariaceae) had remained capable for germination (Kivilaan, B andurski, 1981). Duvel in his experiment from 1902 showed that the average life 
Table 1

Mean time of keeping high germination (in optimal storing conditions) for selected species of agricultural and horticultural importance (Heit, 1944: Roberts, 1973; Lew is, 1958; Nagamine, Miyashita, Nishikawa 2000; Panayotov, Stoeva, 2000; changed)

\begin{tabular}{|c|c|c|c|}
\hline Species & $\begin{array}{c}\text { Number of } \\
\text { years }\end{array}$ & Species & $\begin{array}{l}\text { Number } \\
\text { of years }\end{array}$ \\
\hline Allium cepa & $1-3$ & Phlox drummondii & $1-2$ \\
\hline Althaca officinalis & $3-4$ & Pisum sativum & $2-5$ \\
\hline Amaranthus caudatus & $4-5$ & Poa pratensis & $1-3$ \\
\hline Anethum graveolens & $2-3$ & Portulaca grandiflora & $3-4$ \\
\hline Apium graveolens & 3-6 & Primula vulgaris & 2 \\
\hline Capsicum anmunm & $2-4$ & Raphanus sativus & $3-5$ \\
\hline Dactylis glomerata & $2-4$ & Reseda odorata & $2-4$ \\
\hline Festuca rubra & $2-4$ & Rudbeckia spp. & $3-5$ \\
\hline F. pratensis & $2-4$ & Salvia splendens & $1-2$ \\
\hline Lycopersicum esculentum & $4-6$ & Secale cereale & $1-3$ \\
\hline Lolium perenne & $2-4$ & Solanum spp. & $4-5$ \\
\hline L. italicum & $2-4$ & Solanum melongena & $5-6$ \\
\hline Medicago sativa & $3-5$ & Spinacia oleracea & $5-8$ \\
\hline Melilotus alba & $3-4$ & Tagetes spp. & $3-4$ \\
\hline Mesembryanthemum crystallinum & $3-5$ & Trifolium arvensis & $3-4$ \\
\hline Nemesia strumosa & $2-3$ & T. repens & $2-4$ \\
\hline Nicotiana tabacum & $3-5$ & T. pratense & $2-4$ \\
\hline Nigella damascena & $2-4$ & Triticum aestivum & $2-4$ \\
\hline Oenothera biennis & $2-4$ & Triticum vulgare & $2-4$ \\
\hline Paeonia suffruticosa & $3-4$ & Verbena $x$ hybrida & $2-3$ \\
\hline Papaver orientale & $3-5$ & Vicia faba & $7-8$ \\
\hline Petroselinum crispum & $1-3$ & Viola tricolor & $1-3$ \\
\hline Petunia $x$ hybrida & $2-5$ & Zea mays & $1-3$ \\
\hline Perilla frutescens & up to 50 & Zinnia elegans & $3-7$ \\
\hline Phaseolus vulgaris & $3-4$ & & \\
\hline Phleum pratense & $2-4$ & & \\
\hline
\end{tabular}


of seeds varied greatly with the different botanical families, genera and species. After 39 years seeds of 36 out of the 107 plant species tested, amongst them such genera as e.g. tobacco (Nicotiana), clover (Trifolium), celery (Apium) or meadow-grass (Poa), were still viable (Toole, B row n, 1946). The highest percent of germination represented seeds of the plant species from the two botanical families: Solanaceae and Fabaceae (Chepil, 1946). Peterson and Prasad (1998) found out that weed seeds of Scotch broom (Cytisus scoparius [L.] Link., Fabaceae) could lay in the soil for over 30 years and still germinate. They have thick pericarp and high multiplication coefficient.

Genetic and physiological factors important in seed longevity include the species, seed lot and/or cultivar and the original seed quality. The lifetime of seeds depends as well on the soil environment, in which they live during the dormancy. Soil treatment is also very important (D e m o, 1999; J a me s, R a h m a n, 2000). The differences in life history and dispersal strategy of different plants may result on seed longevity too. For some species, the extreme longevity and persistence in the soil seed bank is a strategy for exploiting newly distributed sites, while the alternative way of propagation of other agricultural weeds depends more on dispersing the seeds widely in space and in contrast less on extreme seed longevity (Conn, Deck, 1995; Le ck, Parker and Simps on, 1989). Knowledge of seed survival is essential to understanding weed population dynamics and for making management decisions in day-to-day farming. In Agriculture, there is a term of the minimal percentage of germinating seeds of agricultural crops, which is of interest to a farmer or horticulturalist. This value depends upon a species. For example, commercial seeds of sugar beet should keep their germination between 95 and $100 \%$, whereas for Verbena seeds $-40 \%$ would be enough. Therefore, the longevity expectations towards the seeds are different. With the mentioned sugar beet seeds one expects them to be able to germinate and emerge in the field for $1-2$ years, for seeds of some flowers $-4-5$ years. This results in practical guarantee given by commercial seed companies for their sown seeds being for sugar beets and flower seeds $1-2$ and up 5 years, respectively.

\section{SEED LONGEVITY AS A RESULT OF CHANGES IN THEIR ORGANS, TISSUES AND CELLS}

Damage to cellular membranes during the seed ageing process is manifested as an increase of solute and electrolyte leakage from seeds during imbibition and as biochemical and physical changes in phospholipids, the major membrane components. These deteriorative changes include: abnormalities of mitochondrial and plastid inner and outer membranes, lobbing of the nuclear envelope, fragmentation or loss of endoplasmic reticulum and the Golgi bodies, dissolution of the bounding membrane of vacuoles and protein bodies, fusion of lipid droplets to form larger bodies or irregular pools, discounties in the plasmalemma and its withdrawal from the cell wall and the occasional appearance of floccular material in the extrapropiastic space (S mith, B erjak, 1995). The extent and leakage rate of intracellular substances depends on several factors including amongst others the plant species, seed quali- 
ty. specific chemical compound. membrane condition and presence or absence of morphological barriers, e.g. seed coat integrity (Bereśn ie w i c z et al.. 1995: Lee et al., 1995; Sung. Chiu, 1995: Taylor et al., 1995). In sunflower osmoprimed seeds no increase in electrolyte leakage was observed during ageing ( $\mathrm{Chojnowski}$ et al., 1997).

The ability of seeds to survive the withdrawal of water during prolonged storage must result in existence of a mechanism for protecting the integrity of the seed cellular membranes. Sucrose can alter the physical characteristics of a membrane phospholipid. causing it to retain characteristics of hydrated lipid even when water is absent. This mechanism is strengthened by the presence of an oligosaccharide such as raffinose. which restricts or prevents the crystallization of sucrose. A similar in vivo reaction between phopholipids and sugars may have direct relevance to the viability of seeds (Caffrey et al., 1988). On the other hand, it is unlikely that changes in oligosaccharides alone are responsible for the reduction in seed longevity ( $\mathrm{Suni}$ tha. Bradford. 2001).

In aged seeds, the decrease in phospholipid level is noticed ( $\mathrm{B}$ a s a $\mathrm{v}$ a r a ja $\mathrm{p}$ pa et. al.. 1991; Pukacka. 1991). Autoxidation and enzymatic oxidation of lipids generate changes in unsaturated fatty acids in the phospholipid fractions, which are in turn a free radical chain reaction. These biochemical reactions are assumed to be the primary mechanism by which free radical injury is imposed on plant membranes ( $\mathrm{B} \mathrm{e} \mathrm{w} \mathrm{-}$ ley. 1986; Hailstones, Smith, 1988 and 1989; Trawatha et al.. 1995; Michalczyk et al., 1998: Shan et al., 2000). The evidence about the relationship between the loss of viability and free radical processes in seeds are often conflicting. For example, for soybean (Glycine max L.) seeds the positive relationship between loss of seed viability and lipid peroxidation was found but, on the other hand. lack of relationship between loss of viability and changes in fatty acid composition together with changes to antioxidants was also reported (Priest le y, Le opold, 1979; Priestley et al., 1980; Hailstones, Smith, 1988). This might be a result of linking two quite different measurements: damage and viability. For a given tissue damage, the evidence for free radical processes is rather good, but in case of many other seeds. no relationship was found between the loss of seed viability and free radical accumulation. The explanation of this phenomenon may partly come from the differences in treatment of the biological material before analysis and lack of the information about the time that had elapsed between death of the seed and the free radical level determination (Hendry, 1993; Michalczyk et al., 1998).

Loss of viability by seeds during prolonged storage is accompanied by decline amounts and reduced levels of enzymatic activities of different enzymes. Changes in profiles as well as the loss of some forms of izoenzymes such as peroxidase. acid phosphatase, dehydrogenase, esterase and aminopeptidase are associated with the age of seeds. For example, the acid phosphatase activity declined stronger in embryos than in endosperms. Similarly, decreased amylase activity and the reduced rate of its synthesis had been reported in the aged wheat seeds (Petruze lli, Tar a n to, 1990; Livesley, B ray, 1991). Loss of activity of detoxifying enzymes, mainly catalase, glutathione reductase and lipoxygenase, whereas superoxide dismutase was the least affected and was probably not involved in seed deterioration during ageing, were also 
present in aged seeds. The marked decrease of lipid-soluble antioxidants levels was another symptom of seed ageing (Pukacka, 1991; S ung, Chiu, 1995; Bailly et al., 1996). This disappearing activity of the enzymes is related to following, during the deterioration of seeds, processes of proteins degradation and denaturation (Roberts, 1972; Harrington, 1973; A quila, 1994; B ailly et al., 1996). These, in turn, result in damaging the seed's protein synthesis system. Free radicals, toxic and mutagenic compounds, as well as activity of the carboxinucleases may eventually affect the properties of DNA. The loss of DNA integrity is probably the source of chromosomal aberrations and impaired transcription observed when seeds of low viability germinate (Cheah, Osborne, 1978; Grzesiuk, Kulka, 1981; Osborne, Boubriak, 2000; Chwedorzewska et al., 2001). When the seed storage time is prolonged, the frequency of anaphase chromosomal aberrations was increasing (S aw icka, S adowska, 1990). Other theory (Hendry, 1993) suggests that damage to nucleic acids and membranes involves the action of activated oxygen, which might be playing a crucial role in a loss of viability in seeds.

Seeds rich in lipids have a slight tendency to live shorter (Villiers, 1973). Seeds of dicotyledonous species under soil conditions remain viability and longevity longer than the monocotyledonous ones (Lew is, 1958). A study of the relationship between lipid stability and longevity in legumes and tomato seeds showed no statistically significant correlation between longevity and total lipid unsaturation, tocopherol levels or other protection and vulnerability factors. A significant negative correlation between linolenic acid levels per a unit of total tocopherols and longevity were found when only leguminous seeds were examined. This may point to possible structural or genetic components affecting longevity (Ponquet et al., 1992). D a o et al., (1999) have found that longevity in soybean is a simple, qualitatively-inherited trait conditioned by a few major genes. They also suggested that the seed longevity could be improved by individual plant selection in the early segregating generations.

Changes in the lipid components of seeds, like some differences in the glassforming tendencies and in the first-order melting behaviour of lipids, are associated with the seed deterioration. The progressive decrease in the energy of the melting endotherm occurred at a similar rate as the loss of vigour and suggests that changes in lipids occur during the process of seed ageing and are not a result of seed mortality. The mechanism, by which the physical properties of storage lipids changed in the process, has been still unknown. Nevertheless, two hypotheses on this matter are suggested: the chemical composition of lipids is altered during storage and/or the physical arrangement of the lipids changes during storage (Vertucci, 1992).

Dry seeds may exist in the glassy state, an amorphous, non-equilibrium condition, in which a liquid achieves such a high viscosity that it resembles a solid. This transition to the glassy state depends upon the increasing concentration of sugars as water is withdrawn, and also upon the temperature. Few beneficial functions of the glassy state in seeds have been suggested: it serves to suppress the deterioration reactions, it has been found to protect macromolecules such as enzymes from being denatured, it may play a role in the protection of membrane integrity by sugars, it can suppress the tissue collapse as water is withdrawn, it helps to avoid the crystalization of cytoplasmic components and increases resistance to water loss (Koster, 1991; 
Le opold et al., 1994). In maize seeds, it was found that raffinose serves to amplify substantially the magnitude of the glass signal and this, in turn, is correlated with enhanced stability of the seed under conditions of accelerated ageing (B e rn a l - L u g o, Leopold, 1995).

B u it in k et al. (1998a, b) stated that longevity of seeds is evidently related to the molecular mobility in the cytoplasm. They found out a linear relationship between the logarithm of the rotational motion in the cytoplasm of the seeds and the halfviability time in relation to water content (B uitink et al., 2000). The same authors assumed that oligosaccharides do not play an important role in the stabilisation of the cytoplasmic matrix in seeds by decreasing the molecular mobility of intracellular glass as a result of increasing glass-to-liquid transition temperature.

Seed priming in all its forms, commercially done in seed companies in recent years, to increase their field emergence rate and to make field plants establishment more even, has negative effects on seed longevity. Primed seeds, although, get better price in trade, are poorer in terms of their potential for storage. Such seeds lose their longevity quicker and are much more difficult to store than the check seeds. The mechanism of this phenomenon is not yet completely cleared out. B rug gin k et al., (1999) discovered that reduced longevity of seeds after priming can be partially restored by a combined heat shock and dehydration treatment. On the other hand, Pow ell et al. (2000) found that priming of the cauliflower (Brassica oleracea var. botrytis) low vigour seeds had improved their longevity. The problem has had a practical importance and is a matter of an intensive seed companies studies. Their results though may not be published as financed by private breeders.

\section{IMPORTANCE OF THE NATURAL CONDITIONS}

The seed longevity is affected by its genetic properties, especially those which determine their structure and by the environment conditions (Passam, Lambropoulos and Khan, 1997; Tang et al., 1999; Górski, 1999; Bakker et al., 2000; Dixit et al., 2001; Yogendra, Ram 2001). The nature affects development, growth and structure of the seed. The most important natural factors affecting seed longevity are: temperature, humidity, light conditions and presence of micoflora in the environment, in which the seed had developed and matured and the others e.g. passage through birds (McKee, Musil, 1948; Grzesiuk, 1967; Heydecker, 1973; Grzesiuk, Kulka, 1981; Lityński, 1982; Bochenek et al., 2000; Renne etal., 2001; Witkowski, Wilson, 2001).

High temperature, solarity and low moisture of the environment are causing a slowing-down of the metabolic processes and in most cases stimulate seed longevity (Grzesiuk, 1967; Ellis, Pieta Filho, 1992). In case of the higher relative humidity, low temperature may slow down the process of seed ageing. The approach to the problem of seed longevity must be then different when seeds are stored than when seeds are sown. In the field condition, from the farmer's point of view, more important than seed moisture content is the physiological maturity of the seeds. Seeds sown to the soil will germinate according to theirs own rhythm. That is an important 
aspect in the strategy of a species (Roberts, Chancellor, 1979; Gutterman, 1980/81). If the seeds are dormant, they will not germinate despite their higher moisture content (Villiers, 1973). In rice plants, seeds showed bigger longevity, if they came from the mother plants, which were grown at lower temperatures (Ell is, Hong and $\mathrm{J}$ a c k s on, 1993). In more wet years, there is bigger occurrence of fungi, bacteria and viruses on seeds, which infest and attack seeds shortening their longevity. High temperature and insolation, in this aspect, lower the number of organisms infecting seeds and prolong the seed longevity (Grzes iuk, 1967; Grzesiuk, Kulka, 1981; B ochenek et al., 2000). Insolation has also effect on dormancy of seeds of some species. It can be broken though (in photophilic species) or initiated (in photophobic species). Primary dormancy of seeds is guaranteeing their longevity (Grzesiuk, Kulka, 1981).

Both temperature and an air relative humidity have also an effect on the final seed testa structure, which in turn affects the seed viability (Crocker, 1909; B ochenek et al., 2000). A good example here are hard seeds of the Leguminosae species. They can stay in a dormancy stage longer than the seeds of other species. The best development of these species is when the weather is dry and warm. Temperature and air relative humidity have effect on dry matter content in seeds, and they in turn affect the seed longevity (B o chene k et al., 2000; R a o et al., 2002). In the seeds of some species, however, it has been found out that the biggest seed longevity is not equal to the moment of seed harvesting stage i. e, when their dry matter content is the highest. The seeds may possess the highest longevity and viability also when there is a delay in relation to the point of their maximum dry matter content (Fig.1) (Ka me swara et al., 1991; Pieta Filho, Ellis, 1991; Ellis, Pieta Filho 1992; Demir, Ellis 1993; Ellis et al.,1993).

Fig. 1

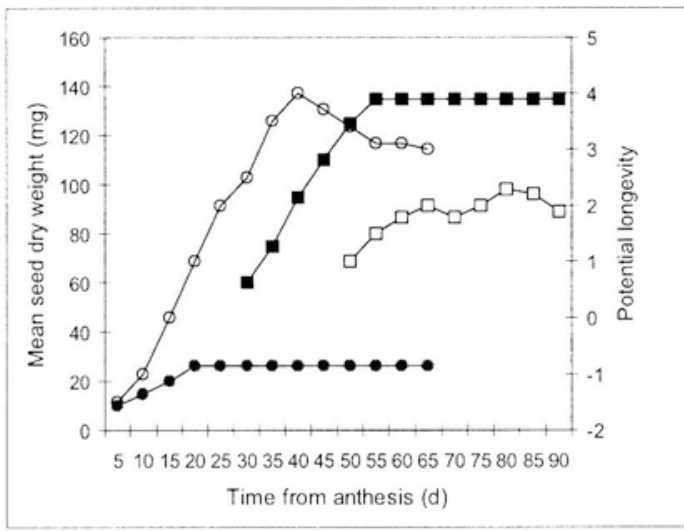

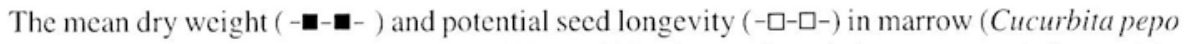
L.) cv. Long Green Bush (Demir, Ellis, 1993, changed) and the mean seed dry weight (---) and potential seed longevity (-O-O-) in rice (Oryza sativa L.) cv. Ketan Amnera (Ell is et al., 1993, changed) 


\section{THE IMPORTANCE OF THE SEED STORAGE CONDITIONS}

Seeds of the majority of species from the orthodox group are stored in practice from a few months up to a few years, and in incidental cases - till several years (Bewley, B lack, 1994). Their seed moisture content is 6-15\%. Only in unusual cases their moisture content goes below 4-6\% (Murdoch, Ellis, 1992; Hong et al., 2001). Further lowering of moisture content of these seeds only to certain level means prolonging their viability. These minimal levels for seeds of goose-foot (Chenopodium ssp.), sun flower (Helianthus annuus L.) and flax (Linum ssp.), when stored in hermetic bags at $65^{\circ} \mathrm{C}$ are $4.1 \%, 2.04 \%$ and $2.7 \%$, respectively (Ell is et al., 1988). When lowering seed moisture content from $4.5 \%$ (rape) to $6.5 \%$ (vetch), further lowering of seed moisture content does not improve their longevity (Ellis et al., 1989). Lowering of seed moisture of bean seed below $3.26 \%$ did not improve their longevity when storing them at $65^{\circ} \mathrm{C}$ (E1l is et al., 1990; K w ong et al., 2001). For the pepper seeds though storing seeds with $10 \%$ moisture content had better effect on their germinability than when seeds had 5.8\% water ( $\mathrm{Sundstrom}, 1990$ ). For tomato seeds, storing seeds with $5 \%$ moisture content in polylaminated aluminium foil pouches let them keep their viability above the certification standard $(70 \%)$ for 8 months longer than for seeds with $4 \%$ moisture content (S a h o o et al., 1999). Seed moisture content is a crucial parameter in storing cereal grains. This is the easiest way to improve their longevity. The study of the moisture relations of seed longevity in Astronium urundeuva (Fr. All.) Engl. showed the negative logarithmic relationship between seed moisture content and longevity (Medeiros et al., 1998). Pelleting of tomato seeds had a significant importance on their storability and resulted in lower germination (Sirimathi et al., 2000). Seeds of many species from the subtropical and tropical area and only few from a temperate zone belong to the group recalcitrant ( $\mathrm{P}$ a $\mathrm{m} \mathrm{m}$ e $\mathrm{n}$ ter et al., 2000; Probert, Hay, 2000). Their seeds keep their germination capacity only, if their moisture content is more than $30 \%$. In both cases however, standard conditions do not guarantee keeping their longevity, though it is known that seeds of some tropical trees considered to belong to the recalcitrant group, when lowering their moisture content, surprisingly - increase their longevity ( $\mathrm{N}$ a y al et al., 2000). Storing temperature as well as the type of the container also can affect the viability of seeds from the recalcitrant group ( $\mathrm{N}$ a y al et al., 2001). Neem (Azadirachta indica A. Juss) seeds are desiccation-tolerant to intermediate moisture level (11.8\%) and thus can be categorized under intermediate storage behaviour (Varghese, Naithani, 2000). The problem of seed longevity in commercial agriculture is met only in few cases, because it is troublesome and expensive (Lit y ńs k i, 1970; Th o m so n, 1978; Lityński, 1982; Panday, 1989). This concerns extremely precious and valuable breeding materials and materials of plant collections or gene banks (Hołu bow ic z, 2000). The conditions of storing such seeds are than described by the same three parameters which are checked in the short-term storage. These are: seed moisture content, temperature of the environment of storing seeds and its relative humidity. The differences are dealing with the level of these factors. For example for Welsh onion (Allium fistulosum L.) seeds the increase of seed moisture content resulted in the significant decrease of seed vigour (Yan p ing et al., 2000). Seeds, which we want to 
store for long time and eventually to have a long longevity must have the highest possible germination capacity. This could be reached through, among other factors, a proper harvest time. They should also have seed moisture content from 4 to $6 \%$ and be packed into hermetic bags, i. e. impermeable for moist (D e m i r, 1994; Z heng et al., 2001). A low temperature is also an important factor helping to prolong seed's longevity. The best, if it ranges from $-20^{\circ} \mathrm{C}$ to $12^{\circ} \mathrm{C}$. It is also possible to keep seeds for this purpose in lower temperatures, e. g. in liquid nitrogen. The relative humidity of the air, in which the seeds are stored hesitates from 35 to $40 \%$ (Mos s, 1938; J u s t i ce, Bass, 1978; Bewley, Black, 1994; Hay, Probert, 1995; Hay et al., 1997; Podlaski, 2000). It is also possible to calculate seed longevity theoretically based it on equilibrated seed moisture content and temperature (Ch en, J a y s, 2000). In the future, in seed quality testing, seed longevity measurements may become one of the routinely tested parameters the same way as seed vigour, viability or health. They will provide a farmer with additional, essential information about actual value of a given seed lot. It is quite probable that the measurement will be based on a nondestructive determination method (Kle in et al., 2002).

Today we can not exclude a possibility of storing seeds in space, in the future. We know, that when keeping the same conditions, the seeds storage capacity exceed the one of the seeds kept on the Earth (Musgrave, 2002).

\section{LITERATURE}

Aquila A. D., 1994. Wheat seed ageing and embryo protein degradation. Seed Sci. Res., 4: 293-298.

Bailly Ch., Benamar A., Corbineau F., Côme D., 1996. Changes in malondialdehyde content and in superoxide dismutase, catalase and glutathione reductase activities in sunflower seed as related to deterioration during accelerated aging. Physiol. Plant., 97: 104-110.

Bakker J. P., Bekker R. M., Thompson K., 2000. From a seed bank database towards a seed database. Z. Okol. und Natur., 9: 61-72.

Basavarajappa B. S., Shetty H S., Prakash H. S., 1991. Membrane deterioration and other biochemical changes, associated with accelerated ageing of maize seeds. Seed Sci. \& Technol., 19: 279-286.

Bereśniewicz M. M., Taylor A. G., Goffinet M. C., Terhune B. T., 1995. Seed coat integrity in relation to leakage in onion (Allium cepa L.) and leek (Allium porrum L.). Plant Var. Seeds, 8: 87-95.

Bernal-Lugo I., Le op old A. C., 1995. Seed stability during storage: raffinose content and seed glassy state. Seed Sci. Res., 5: 75-80.

B ew le y J.D., 1986. Membrane changes in seeds as related to germination and the perturbations resulting from deterioration in storage. In: Physiology of Seed Deterioration. CSSA (Crop Science Society of America, ed.) Spec. Pub., 11: 27-45.

Bewley J. D., B lack M., 1982. Physiology and Biochemistry of Seeds, vol. 2, Viability, dormancy and environment control. Springer, New York, NY.

Bewley J. D., B lack M., 1994. Viability and Longevity of Seeds. In; Seeds. Physiology of Development and Germination. Plenum Press, New York and London: 388-401. 
Bochenek A., Górecki P., Grzesiuk S., 2000. General Properties of Seeds. In: „Seed Science and Technology" (ed. Duczmal K. W., Tucholska H.), 127-137, 150-164 (in Polish).

Bruggink G. T., Oom s J. J. J., Van der Toorn P., 1999. Induction of longevity in primed seeds. Seed Sci. Res., 9: 49-53.

Buitink J., Claessens M. M. A. E., Hemming a M. A. Hoekstra F. A., 1998a. Influence of water content and temperature on molecular mobility and intracellular glasses in seeds and pollen. Plant Physiol., 118: 531-541.

Buitink J., Walters C., Hoekstra F. A., Crane J., 1998b. Storage behaviour of Typha latifolia pollen at low water contents: interpretation on the basis of water activity and glass concepts. Physiol. Plant, 103: 145-153.

Buitink J., Hem ming a M. A., Hoekstra F. A., 2000. Is there a role for oligosaccharides in seed longevity? An assessment of intracellular glass stability. Plant Physiol., 122: 12171224.

Burnside O. C., Wilson R. G., We isberg S., Hubbard K. G., 1996. Seed longevity of 41 weed species buried 17 years in Eastern and Western Nebraska. Weed Sci., 44: 74-86.

Caffrey M.. Fonseca V., Leopold A. C., 1988. Lipid-Sugar Interactions. Plant Physiol.. 86: 754-758.

Ca m b a ge R. H., C. B. E., F.L.S., 1928. Acacia seedlings Part XIII. Royal Society of New South Wales J. Proc., 62: 152-167.

Che ah K. S. E., Osborne D. J., 1978. DNA lesions occur with loss of viability in embryos of ageing rye seed. Nature, 272: 593-599.

Chen C., Jays D. S., 2000. Relating equilibrium relative humidity and temperature to seed longevity. Agric. Engin. J., 9: 129-138.

Chepil W. S., 1946. Germination of weed seeds. I. Longevity, periodicy of germination, and vitality of seeds in cultivated soil. Scien. Agric., 26: 307-346.

Chojnowski M., Corbineau F., Côme D., 1997. Physiological and biochemical changes induced in sunflower seeds by osmopriming and subsequent drying, storage and aging. Seed Sci. Res., 7: 323-331.

Chwedorzewska K., Bednarek P. T., Puchalski J., 2001. Trial application of the AFLP technique for evaluation the genetic changes resulting from long-term storage and reproduction of rye (Secale cereale L.) seeds. Biul. IHAR, 216: 111-116 (abstract).

Conn J.S., Deck R. E., 1995. Seed viability and dormancy of 17 weed species after 9.7 years of burial in Alaska. Weed Sci., 43: 583-585.

Crocker W., 1909. Briefer articles. Longevity of seeds. Bot. Gaz., 47: 69-72.

D a o P. T., Ram H. H., Ya da v R., 1999. Genetics of seed longevity in soya bean (Glycine max L. Merrill). Trop. Agric., 3: 179-182.

Davis J.C., Procter J. D., Southon J.R., Caffee M.W., Heikkinen D. W., Roberts M. L., Moore T. L., Turteltaub K. W., Nelson D. E., Loyd H. D., Vogel J.S., 1990. LLNL/UC AMS facility and research program. In: Nuclear instruments and methods in physics research. B52, 269-272. Elsevier, North Holland.

De m ir I., 1994. Tohum neminin kabak (Cucurbita pepo L. Sakiz Kabagi) tohumlarini depolama ömrüne etkisi. Bahçe, 23: 53-58.

Dem ir I., Ell is R. H., 1993. Changes in potential seed longevity and seedling growth during seed development and maturation in marrow. Seed Sci. Res., 3: 247-257.

Demo M., 1999. Regulation of soil weed infestation in the half-vesture period using nonchemical methods. Regulácia zaburinenosti pôdy v medziporastovom období nechemickými metódami, Acta Hort. et Regiotec., 2: 4-9 
Dixit G. P.. Singh B. D., Joshi A. K.. 2001. Genetics of seed longevity in spring wheat. Indian J. Gen. Plant Breed.. 61: 98-100 (abstract).

Ellis R.H..Hong T. D.. Roberts E. H., 1988. A low-moisture-content limit to logarithmic relations between seed moisture content and longevity. Ann. Bot.. 61: 405-408.

Ellis R.H., Hong T. D., Roberts E. H., 1989. A comparison of the low-moisture-content limit to the logarithmic relation between seed moisture and longevity in twelve species. Ann. Bot., 63: 601-611.

Ellis R.H.. Hong T. D.. Roberts E. H.. 1990. Moisture content and longevity of seeds of Phaseolus vulgaris. Ann. Bot.. 66: 341-348.

Ellis R. H.. Pieta Filho C.. 1992. Seed development and cereal seed longevity. Seed Sci. Res.. 2: 9-15.

Ellis R. H., Hong T. D., Jackson M. T., 1993. Seed production environment, time of harvest, and the potential longevity of seeds of three cultivars of rice (Orya sativa L.) Ann. Bot.. 72: 585-590.

Górsk i M.. 1999. Seed viability of the flax in the longterms storage. Biul. IHAR. 210:189-192 (in Polish).

Grzesiuk S.. 1967. Seed Physiology. PWRiL. Warszawa (in Polish).

Grzesiuk S.. Kulka K.. 1981. Physiology and Biochemistry of Seeds. PWRiL. Warszawa (in Polish).

Gutterman Y.. 1980/81. Annual rhythm and position effect in the germinability of Mesembryanthemum nodiflorum. Israel J. Bot., 29: 93-97.

Hailstones M. D., S mith M. T., 1988. Lipid peroxidation in relation to declining vigour in seeds of soya (Glycine max L.) and cabbage (Brassica oleracea L.). J. Plant Physiol.. 133: $452-456$.

Hailstones M. D., Smith M. T., 1989. Thermally-derived volatile aldehydes in relation to seed viability in soybean seeds. Seed Sci. \& Technol.. 17: 649-658.

Harrington J. F. 1973. Biochemical basis of seed longevity. Seed Sci. \& Technol.. 1: 453-461.

Hay F. R., Probert R. J., 1995. Seed maturity and the effects of different drying conditions an desiccation tolerance and seed longevity in foxglove (Digitalis purpurea L.). Ann. Bot., 76: 639-647.

Hay F. R., Probert R. J., Coomber S. A., 1997. Development of desiccation tolerance and longevity in seeds from detached capsules of foxglove (Digitalis purpurea L.). Ann. Bot., 79: 419-427.

Heit C. E., 1944. Recent findings in laboratory germination and longevity of New Zealand spinach seed. Proc. AOSA, Columbus. Ohio, July 17-21: 115-121.

Hendry G. A. F., 1993. Oxygen, free radical processes and seed longevity. Seed Sci. Res., 3: 141-153.

Hey decker W., 1973. Seed Ecology. Proc. 19th Easter School Agric. Sci., Univ. Nottingham.

Hołubow ic z R., 2000. Seed Packaging and Bagging. In: ,.Seed Science and Technolog”. (ed. Duczmal K. W., Tucholska H.). 287-295 (in Polish).

Hong T. D.. A hmad N. B., Murdoch A. J.. 2001. Optimum air-dry storage conditions for sweet orange (Citrus sinensis (L.) Osbeck) and lemon (Citrus limon (L.) Burm. f.) seeds. Seed Sci. \& Technol., 29: 183-192.

J ustic e O. L., B as s L. N., 1978. Effect of storage environment on seed longevity. In: Principles and Practices of Seed Storage. Agric. Handbook 506, USDA, Washington D.C.: 26-80.

James T. K.. Rahman A., 2000. Longevity of buried ragwort seed in four soils. Proc. Conf., New Zealand Plant Protection Society, Commodore Hotel, Christchurch, 8-10 August 2000 (abstract). 
Kameswara R. N.. Appa R. S., Mengesha M. H.. Ell is R. H.. 1991. Longevity of pearl millet (Pennisetum glaucum R. Br.) seeds harvested at different stages of maturity. Ann. Appl. Biol. 119: 97-103.

Klein J.P.. Santosa E., B oamfa J., Hebbe J., Harren F., 2002. Trace gas analysis for rapid non-destructive determination of seed viability. Abstracts of 26th Inter. Hort. Congress. Toronto, Canada, 549.

Koster K. L., 1991. Glass formation and desiccation tolerance in seeds. Plant Physiol.. 96: 302-304.

Kivilaan A., Bandurski R. S., 1981. The one hundred-year period for dr. Beal's seed viability experiment. Amer. J. Bot., 68: 1290-1292.

Kwong F.. Stodolski L., Mari J., Gurusinghe S.H., Bradford K. J., 2001. Viability constants for delphinium and salvia seeds. Seed Technol.. 23: 113-125 (abstract).

Leck M. A.. Parker V. T.. Simpson R. L., 1989. Ecology of soil seed banks. Academic Press.

Lee S. S.. Taylor A. G.. Bereśniewicz M. M.. Paine D. H.. 1995. Sugar leakage from aged leek. onion. and cabbage seeds. Plant Var. Seeds. 8: 81-86.

Leopold A.C.. Sun W. Q.. Bernal-Lugo I., 1994. The glassy state in seeds: analysis and function. Seed Sci. Res.. 4: 267-274.

Lew is J., 1958. Longevity of crop and weed seeds. I. First Interim Report. Proc. of ISTA, 23: 340-354.

Lityński M., 1970. Seed Biology and Science. PWN, Warszawa (in Polish).

Lityński M., 1982. Environment of Seed Storage. In: „Biological Principles of Seed Science and Technology". PWN, Warszawa: 59-64, 340-381 (in Polish).

Livesley M. A., Bray C. M., 1991. The effects of ageing upon $\alpha$-amylase production and protein synthesis by wheat aleurone layers. Ann. Bot., 68: 69-73.

McKe e R.. Musil F.. 1948. Relation of temperature and moisture to longevity of seed of Blue lupine, Lupinus angustifolius. Austrian Winter Fieldpea. Pisum sativum arvense, and Hairy Vetch, Vicia villosa. J. Amer. Soc. Agron.. 48: 459-463.

Medeioros A.C.S., Probert R. J., S ader R., S m ith R. D., 1998. The moisture relations of seed longevity in Astronuim urundeuva (Fr. All.) Engl. Seed Sci. \& Technol., 26: 289-298.

Michalczyk D. J., Górecki R. J., Kulka K., Rejowski A., 1998. Changes in phospholipid fractions of field bean (Vicia faba var. minor Harz) seeds stored at different temperatures. Plant Breed. and Seed Sci., 42: 37-46.

Mos s E. H., 1938. Longevity of seed and establishment of seedlings in species of Populus. Bot. Gaz., 99: 529-542.

Murdoch A. J., Ellis R. H., 1992. Longevity, Viability and Dormancy. In: „Seeds. The Ecology of Regeneration in Plant Communities". (ed. Fenner M.), CAB Intern. Tnowbridge. UK: 193-229.

Musgrave M. E., 2002. Seeds in space. Seed Sci. Res., 12: 1-16 (abstract).

Nagamine T., Miyashita S., Nishikawa T., 2000. Seed longevity of perilla (Perilla frutescens (L.) Britt var. frutescens). Seed Sci. \& Technol., 3: 875-879.

Nayal J. S., Thapliyal R. C., Rawat M. M. S., Phartyal S. S., 2000. Dessication tolerance and storage behaviour of neem (Azadirachta indica A. Juss.) seeds. Seed Sci. \& Technol., 28: 761-767.

Nayal J.S., Thapliyal R. C., Phartyal S.S., Joshi G., 2001. Longevity of neem (Azadirachta indica A. Juss.) seed-the effect of storage containers. Seed Sci. \& Technol., 29: 697-681 (abstract). 
Ohg a I., 1926. The germination of century-old and recently harvested Indian lotus fruits, with special reference to the effect of oxygen supply. Amer. J. Bot., 13: 754-759.

Osborne D. J., B oubriak I. I., 2000. Life and death in the embryos of seeds. Proc. of a Seed Symposium on: Current research on seeds in New Zealand. Massey Univ., Palmerston North, 12 Feb. 1999 (abstract).

Pand a y D. K., 1989. Amelioration of the effect of ageing in onion seeds. Indian J. Physiol., 32: 379-382.

Pammenter N. W., B erjak P., Walters C., 2000. The effect of drying rate on recalcitrant seeds, lethal water contents, causes of damage and quantification of recalcitrance. In: „,Seed Biology. Advances and Applications”. (ed. Black M., Bradford K. J., VacuezRamos J.). CABI Publ. Intern., Oxon, UK: 215-222.

Panay otow N., S toev a N., 2000. Viability and some indices of seeds of different age from vegetable species pepper (Capsicum annuum L.). Capsicum \& Eggplant Newsletter 19: 111-114 (abstract).

Passam H. C., Lambropoulos E., Khan E. M., 1997. Pepper seed longevity following production under high ambient temperature. Seed Sci. \& Technol., 25: 177-185.

Peterson D. J., Prasad R., 1998. The biology of Canadian weeds. 109. Cytisus scoparius (L.) Link. Canad. J. Plant Sci., 78: 497-504.

Petruzelli L., Taran to G., 1990. Amylase activity and loss of viability in wheat. Ann. Bot., 66: $375-378$.

Picta Filho C., Ellis R. H., 1991. The development of seed quality on spring barley in four environments. 1. Germination and longevity. Seed Sci, Res., 1:163-177.

Podla ski S., 2000. Moisture and Temperature of Seed Storage. In: „Seed Science and Technology". (ed. Duczmal K.W., Tucholska H.), 1: 282-283 (in Polish).

Ponquet R. T., S mith M. T., Ross G., 1992. Lipid autoxidation and seed ageing: putative relationships between seed longevity and lipid stability. Seed Sci. Res., 2: 51-54.

Powell A. A., Yule L. J., Hai-Chun Jing, Groot S. P. C., Bino R. J., Pritchard H. W., 2000. The influence of aerated hydration seed treatment on seed longevity as assessed by the viability equations. J. Exp. Bot., 51: 2031-2043.

Priestley D. A., Le o pold A. C., 1979. Absence of lipid oxidation during accelerated aging of soybean seeds. Plant Physiol., 63: 726-729.

Priestley D. A., McBride M. B., Leopold A. C., 1980. Tocophereol and organic free radical levels in soybean seeds during natural and accelerated aging. Plant Physiol., 66: 715-719.

Probert R. J., Hay F. R., 2000. Keeping Seeds Alive. In: „Seed Technology and its Biological Bases". (ed. Black M., Bewley J. D., Academic Press, Shefield, UK: 375-410.

Pu k a c k a S., 1991. Changes in membrane lipid components and antioxidant levels during natural ageing of seeds of Acer platanoides. Physiol. Plant., 82: 306-310.

Rao N. K., Bramel P. J., Reddy K. N., Singh S. D., Girish a. G., Rao S. A., Mahalakshmi V., 2002. Optimizing seed quality during germplasm regeneration in pearl millet. Gen. Res. Crop Evol., 49: 153-157 (abstract).

Renne I. J., S pira T. P., B ridges W. C., Jr., 2001. Effects of habitat, burial, age and passage through birds on germination and establishment of Chinese tallow tree in coastal South Carolina. J. Torrey Bot. Soc., 128: 109-119 (abstract).

Roberts E. H., 1972. Viability of Seeds. Syracuse Univ. Press, 253-306.

Roberts R. H., 1973. Predicting the storage life of seeds. Seed Sci. \& Technol., 1: 499-514.

Roberts H. A., Chan cellor R. J., 1979. Periodocity of seedling emergence and achene survival in some species of Carduus, Cirsium and Onopordum. J. App. Ecol., 16: 641-647. 
Roos E. E.. Davidson D. A.. 1992. Record Longevities of Vegetable Seeds in Storage. HortScien.. 27: 393-396.

Sahoo P.. Swain S. K.. Das B. C.. Dash S. K.. Kar D. K.. 1999. Effect of containers on viability and vigour of tomato seeds stored at varying initial moisture levels. Orissa $\mathrm{J}$. Hort., 27: 84-91.

S aw ick a E. J., S a d ow sk a A., 1990. Relationship between chromosomal aberrations and longterm seed storage of rye (Secale cereale L.) cv. Dańkowskie Złote. Gen. Pol., 31: 89-97.

Shan X. C.. Weatherhead M. A.. Song S. Q.. Hodgkiss I. J.. 2000. Malondialdehyde content and superoxide dismutase activity in seed of Phaius tankervilliae (Orchidaceae) during storage. Lindleyana. 15: 176-183.

Shen-Miller J., Mudgett M. B.. Schopf J. W.. Clarke S., Berger R., 1995. Exceptional seed longevity and robust growth: ancient sacred lotus from China. Amer. J. Bot., 82: $1367-1380$

Shen-Miller J., Schopf J. W., Harbottle G., Cao Ruiji, Quyang Shu, Zhou Kun Shu. Southon J. R.. Liu GouHai. 2002. Long-living lotus: germination and soil $\gamma$-irradiation of centuries-old fruits, and cultivation. growth. and phenotypic abnormalities of offspring. Amer. J. Bot.. 89: 236-247 (abstract).

Sirimathi P.. Malarkodi K.. Geetha R.. Krishnasamy V., 2000. Influence of presowing pelleting treatment on seed yield and storability of tomato $\mathrm{cv}$. PKM-1. Orissa J. Hort., 28: 33-35.

S mith M. T., Berjak P., 1995. Deteriorative changes associated with the loss of viability of stored dessication-tolerant and dessication-sensitive seeds, In: ,Seed Development and Germination”. (ed. Kigel J., Galili G.), Marcel Dekker, New York, Basel, Hong Kong.

Sundstrom F. J.. 1990. Seed moisture influence on tabasco pepper seed viability, vigour and dormancy during storage. Seed Sci. \& Technol., 18: 179-185.

Sung J. M.. Chiu C. C.. 1995. Lipid peroxidation and peroxide-scavening enzymes of naturally aged soybean seed. Plant Sci., 110: 45-52.

S un itha G., Bradford K. J., 2001. Galactosylsucrose oligosaccharides and potential longevity of primed seeds. Seed Sci. Res., 11: 121-133.

Tang S., TeKrony D. M., Egli D. B., Cornelius P. L., 1999. Survival characteristics of corn seed during storage: II. Rate of seed deterioration. Crop Sci., 39: 1400-1406.

Taylor A. G.. Lee S.S., Bereśniewicz M. M., Paine D. H., 1995. Amino acid leakage from aged vegetable seeds. Seed Sci. \& Technol., 23: 113-122.

Th om s on J. R., 1978. Storage. In: .,The Introduction to Seed Technology”. Leonard Hill, East Kilbride, Scotland.: 92-109.

Toole E. H., Brown E., 1946. Final results of the Duvel buried seed experiment. J. Agric. Res., 72: 201-210.

Trawatha S. E., Te Krony D. M., Hildebrand D. F., 1995. Seed physiology, production \& technology. Crop Sci., 35; 1415-1422.

Varghese B.. Naithan i S.C.. 2000. Desiccation induced loss of vigour and viability during storage in neem (Azadirachta indica A. Juss) seeds. Seed Sci. \& Technol., 28: 485-496.

Vertu c c i Ch. W.. 1992. A calorimetric study of the changes in lipids during seed storage under dry conditions. Plant Physiol., 99: 310-316.

Villiers T. A., 1973. Ageing and the longevity of seeds in field conditions. In: „Seed Ecology”. (ed. Heydecker W.). Proc. 19th Easter School Agric. Sci., Univ. Nottingham: 265-288.

Witk owski E. T. F., Wils on M., 2001. Changes in density, biomass, seed production and soil seed banks of the non-native invasive plant, Chromolaena odorata, along a 15 year chronosequence. Plant Ecol.. 152: 13-27 (abstract). 
Yanping Y., Rongqi G., Qingquan S.., Shengfu L., 2000. Vigour of Welsh onion seeds in relation to storage temperature and seed moisture content. Seed Sci. \& Technol., 28: 817-823.

Yogendra M.. Ram H. H.. 2001. Stability analysis for seed quality components in soya bean [Glycine max (L.) Merill.]. Trop. Agric.. 78: 104-107 (abstract).

Zheng X. Y., Li X. Q., Ma L. P., 2001. Research on freeze-drying and vacuum-drying of orthodox seeds for long-term storage. IPGRI Newsletter for Asia, the Pacific and Oceania, 34: 22-2.3 (abstract).

\section{Niektóre rolnicze aspekty długowieczności nasion (przegląd literatury)}

\section{Streszcze ni e}

Istnieje bardzo wiele danych literaturowych dotyczących długowieczności nasion. Większość z tych prac koncentrowała się jednak wyłącznie na teoretycznych i biologicznych aspektach zagadnienia. Pomimo tego, że część badań dotyczyła praktycznych problemów przechowywania nasion, wigoru czy degeneracji, miały one relatywnie mały związek z nasionami roślin rolniczych, praktyczną uprawą lub ogrodnictwem. Dlatego też wystąpiła potrzeba spojrzenia na ten problem z punktu widzenia producentów nasion i rolników.

Prezentowana praca wypowiada się na temat tego jak długo nasiona roślin rolniczych mogą zachować długowieczność, jak długo ich przechowywanie jest uzasadnione ekonomicznie, jaki jest wpływ składu chemicznego nasion na ich długowieczność, jak mogą być modyfikowane warunki przechowywania nasion w celu ewentualnego zwiększenia ich długowieczności i jaki jest wpływ czynników środowiskowych na końcową długowieczność nasion. Praca zawiera syntetyczne streszczenie na temat najbardziej znaczących gatunków roślin uprawnych i wiele przykładów długowieczności nasion roślin rolniczych. 